whose numbers are certainly known-at the last count there were only 12 in existence. The grant will go to help the considerable efforts that are being made in Japan to preserve both the breeding and the feeding areas of the species.

Altogether 277 mammals and 321 birds are in danger of extinction at this moment. The Revolving Fund can only make a very small nibble at the immense task that this represents, but it can do something, and in its first year it has made a considerable impression. A number of FPS members have sent generous donations; may we urge others to do the same?

The Revolving Fund has been set up to help save urgent casesquickly. Time is very often the most important ingredient for success. Please help.

\title{
FPS TOURS TO INDIA AND KENYA
}

THE first FPS tour to India takes place in February, 1968, as already announced. The tour, whose guides will include $\mathrm{Mr}$. Zafar Futehally, hon. secretary of the Bombay Natural History Society, and Mr. E. P. Gee, member of the India Wild Life Board and well known to FPS members as an authority on Indian wildlife, will visit among other places the Gir Forest (for the Indian lion), the Kanha (tigers) and the Corbett National Parks, the famous Kaziranga sanctuary for the great Indian rhino in Assam and the Manas sanctuary close to the Himalayas where the rare golden langur monkey is found, as well as Bombay, New Delhi, Agra and the Taj Mahal.

The third tour to East Africa, also in February, 1968, will be in Kenya with the emphasis on birds-as many as 500 different species may well be seen in addition to all the usual large game animalslions, elephants, giraffes, antelopes, etc. Lakes Naivasha and Nakuru, Mount Kenya and the Aberdares, Samburu, the Tsavo, Treetops and the coast will all be visited.

A few places are still available on both tours. For details please write to Miss Elizabeth Giles, FPS Administrative Secretary.

\section{Oil Pollution of the Sea}

The good news announced at the Cambridge conference of the International Council for Bird Preservation last July, that the 1962 amendments to the Convention for the Prevention of Pollution of the Sea by Oil would come into force in May this year, has been tragically overshadowed by the disaster of the Torrey Canyon. But the amendments are important. They bring a much larger number and variety of ships within the provisions of the Convention, including naval vessels and tankers as small as 150 tons, prohibit the discharge of oil into the sea by ships of over 20,000 tons, and considerably enlarge the zones in which oil may not be discharged at all. 